Article

\title{
Oleandrin and Its Derivative Odoroside A, Both Cardiac Glycosides, Exhibit Anticancer Effects by Inhibiting Invasion via Suppressing the STAT-3 Signaling Pathway
}

\author{
Young Shin Ko ${ }^{1}$, Trojan Rugira ${ }^{1,2}$, Hana Jin ${ }^{1}$, Sang Won Park ${ }^{1,2}$ and Hye Jung Kim ${ }^{1,2, *(1)}$ \\ 1 Department of Pharmacology, College of Medicine, Institute of Health Sciences, \\ Gyeongsang National University, Jinju 52727, Korea; shini33@naver.com (Y.S.K.); \\ rugirawacu@gmail.com (T.R.); hahaha-_-0001@hanmail.net (H.J.); parksw@gnu.ac.kr (S.W.P.) \\ 2 Department of Convergence Medical Science (BK21 Plus), Gyeongsang National University, \\ Jinju 52727, Korea \\ * Correspondence: hyejungkim@gnu.ac.kr; Tel.: +82-55-772-8074; Fax: +82-55-772-8079
}

Received: 7 September 2018; Accepted: 25 October 2018; Published: 26 October 2018

\begin{abstract}
The cardiac glycosides oleandrin and odoroside A, polyphenolic monomer compounds extracted from Nerium oleander, have been found to have antitumor effects on various tumors at low doses. However, the mechanisms of anticancer effects of oleandrin and odoroside A are not well known. Therefore, in this study, we aimed to investigate the anticancer effects of oleandrin and odoroside A and their associated mechanisms in highly metastatic MDA-MB-231 breast cancer cells and radiotherapy-resistant (RT-R) MDA-MB-231 cells. Our results showed that oleandrin and odoroside A dose-dependently decreased the colony formation and the invasion of both cell lines at nanomolar ranges. Furthermore, oleandrin $(50 \mathrm{nM})$ and odoroside $\mathrm{A}(100 \mathrm{nM})$ reduced octamer-binding transcription factor $3 / 4$ (OCT3/4) and $\beta$-catenin levels and matrix metalloproteinase-9 (MMP-9) activity. Finally, we found that phospho-STAT-3 levels were increased in MDA-MB-231 and RT-R-MDA-MB-231, but not in endothelial cells (ECs), and that the levels were significantly decreased by oleandrin $(50 \mathrm{nM})$ and odoroside A $(100 \mathrm{nM})$. Inhibition of phospho-signal transducer and activator of transcription (STAT)-3 significantly reduced OCT3/4 and $\beta$-catenin levels and MMP-9 activity, ultimately resulting in reduced invasion. These results suggest that the anticancer effects of oleandrin and odoroside A might be due to the inhibition of invasion through of phospho-STAT-3-mediated pathways that are involved in the regulation of invasion-related molecules.
\end{abstract}

Keywords: breast cancer cells; invasion; oleandrin; odoroside A; STAT-3

\section{Introduction}

The sodium/potassium $\left(\mathrm{Na}^{+} / \mathrm{K}^{+}\right)$-ATPase pump (NKP) inhibitors are gaining interest as candidates for cancer treatment. NKP is expressed in various cells such as neurons and cardiomyocytes and is a transmembrane ion transporter that is essential for cell survival, growth, and differentiation [1]. NKP serves as a multifunctional signal transducer and integrator and is responsible for maintaining resting potential and regulating cellular volume, contractility, adhesion, inflammation, and apoptosis [2-5]. Interestingly, it has been reported that the aberrant expression and activity of the pump are involved in the progression of several types of aggressive cancers [6-10], and this pump has been linked to cancer onset, proliferation and metastasis [11]. NKP has four $\alpha$ subunits, three $\beta$ subunits, and one $\gamma$ subunit [12], and the $\alpha 1$ and $\alpha 3$ subunits of NKP are frequently overexpressed in colorectal cancer, glioblastomas, and breast cancer [13-15]. 
Therefore, $\mathrm{Na}^{+} / \mathrm{K}^{+}$-ATPase is a crucial target for the development of anticancer agents. In this respect, cardiac glycosides, which are NKP inhibitors [16,17], could be new therapeutic agents that inhibit cancer cell survival by altering the distribution of NKP in cancer versus normal cells. The anticancer potential of cardiac glycosides has recently been evaluated, and promising data have been generated. For example, some cardiac glycosides, such as digitoxin, digoxin, bufalin, and ouabain, inhibit cancer cell proliferation and block tumor growth by inducing immunogenic cell death [18]. Selected cardiac glycosides (such as digoxin) are undergoing clinical trials $[19,20]$ in multiple types of cancer including non-small cell lung carcinoma, colorectal cancer, breast cancer, melanoma, prostate cancer, and pancreatic cancer.

In particular, oleandrin, the most abundant cardenolide from Nerium oleander, has been the subject of much more extensive research regarding the mechanism of its action in cancer treatment. Oleandrin is a lipid-soluble cardiac glycoside that can effectively inhibit the proliferation of various cancer cells and induce apoptosis [21,22]. In addition, oleandrin can also enhance the effectiveness of radiotherapy [23]. Various studies to elucidate the possible pathways underlying the anticancer activity of oleandrin have been conducted, and it has been suggested that oleandrin which is known as an NKP inhibitor inhibits cancer cell proliferation by decreasing NKP levels as well [24], mitochondrial injury caused by the generation of reactive oxygen species (ROS) [25], activation of caspase-3, leading to tumor cell apoptosis [23], or activation of the DNA damage checkpoint at the G2/M phase [26]. However, the detailed mechanisms of the antitumor activity of oleandrin are still not fully understood.

The signal transducer and activator of transcription (STAT) protein family plays a major role in cancer [27]. STATs regulate the transcription of target genes that control tumor cell proliferation and differentiation, as well as genes encoding proteins with major roles in conditioning the tumor microenvironment [28-30]. Constitutive activation of STAT-3 has been found in invasive and metastatic tumors [31,32]. The activation of Janus kinase (JAK)-2/STAT-3 signaling regulates the growth and maintenance of stem-like breast cancer cells $\left(\mathrm{CD} 44^{+} \mathrm{CD} 24^{-}\right)$[33]. In addition, STAT-3 activation has also been associated with the resistance of tumor cells to chemotherapeutic agents and $\gamma$ radiation $[34,35]$. STAT-3 mediates these effects through its collaboration with various other transcription factors, including nuclear factor- $\mathrm{kB}$, hypoxia-inducible factor- 1 and peroxisome proliferator activated receptor- $\gamma$, and via the upregulation of antiapoptotic gene products. Thus, downregulation of STAT-3 can overcome chemoresistance and radioresistance. However, there have been no studies investigating the effects of cardiac glycosides, such oleandrin and odoroside A, on the STAT-3 pathway.

The narrow therapeutic index of clinically used cardiac glycosides due to their cardiovascular toxicity could limit their therapeutic use $[36,37]$. To overcome this problem, it is necessary to search for cardiac glycoside-derived compounds with the ability to inhibit the proliferation and metastasis of cancer cells without causing cardiovascular damage. In vitro studies have shown that, at nanomolar concentrations, cardiac glycosides are nontoxic to normal cells and may protect them from apoptosis or induce cell proliferation, while in cancer cells, these drugs block cell proliferation and induce cell death [11,22,38-40]. Rashan et al. [41] reported that monoglycosidic cardenolides, including oleandrin and odoroside A isolated from Nerium oleander, exhibit significant anticancer activity. Unlike those of oleandrin, the effects of odoroside A and their underlying mechanisms are not well known.

The conventional therapies for breast cancer patients include surgical removal of the tumor, drug treatment and radiation. However, each therapy has inherent limitations that lead to therapeutic resistance and disease recurrence, ultimately resulting in therapeutic failure. Especially, the radio-resistance of breast cancer cells remains a clinical problem to the maximum efficacy of radiotherapy. Thus, in this study, using highly metastatic MDA-MB-231 and radio-resistant MDA-MB-231 breast cancer cells which were established in our previous study, we compared the anticancer effect of odoroside A with those of oleandrin and explored the associated mechanisms. 


\section{Results}

2.1. Oleandrin and Odoroside A Showed Effective Anticancer Effects Both in MDA-MB-231 and Radiotherapy Resistant (RT-R)-MDA-MB-231 at the Nanomolar Concentrations

First, we determined the effects of oleandrin and odoroside A on the cell viability of breast cancer cells and endothelial cells (ECs) by MTT assay. The results revealed that oleandrin and odoroside A dose-dependently reduced the cell viability of breast cancer cells and ECs at nanomolar concentrations (Figure 1B,C). Interestingly, odoroside A seemed to be less toxic to ECs (IC50: $127 \mathrm{nM}$ ) and breast cancer cells MDA-MB-231 (IC50: 183 nM) and RT-R-MDA-MB-231 (IC50: noncalculated in these doses setting) than oleandrin (IC50: 35 nM in ECs, 72 nM in MDA-MB-231, 183 nM in RT-R-MDA-MB-231, respectively). Since we were more interested in the anti-invasive and antimetastatic effects of the drug candidates than their cytotoxicity due to the fact that cancer metastasis, rather than primary tumors themselves, is responsible for the majority of cancer deaths, we chose concentrations below the IC50s (50 nM for oleandrin and $100 \mathrm{nM}$ for odoroside A) for the next experiments. Accordingly, we examined the time-dependent effects of oleandrin and odoroside A on the cell morphology of MDA-MB-231 and RT-R-MDA-MB-231 cells at 50 and $100 \mathrm{nM}$, respectively. Figure 2A shows that oleandrin (50 nM) and odoroside A (100 nM) induced morphologic changes in MDA-MB-231 cells and RT-R-MDA-MB-231 cells in a time-dependent manner (24, 48, and $72 \mathrm{~h}$ ). Remarkably, both cell lines treated with oleandrin showed morphological changes, such as cell shrinkage, blebbing and disorganization, at 48 and $72 \mathrm{~h}$ (Figure 2A). In addition, oleandrin, and odoroside A significantly decreased colony formation in both cell lines in a dose-dependent manner $(1,10,30$, and $50 \mathrm{nM})$ (Figure 2B). These results suggest that oleandrin and odoroside A have anticancer effects by reducing clonogenicity at doses lower than their IC50s for cell viability; moreover, odoroside A is less toxic than oleandrin but has similar anticancer effects.

\subsection{Oleandrin and Odoroside A Significantly Inhibited the Invasion of $M D A-M B-231$ and RT-R-MDA-MB-231 Cells at Lower Doses than IC50 of Cell Viability}

Next, we determined the effects of oleandrin and odoroside A on the invasion of MDA-MB-231 and RT-R-MDA-MB-231 cells through endothelial cells (ECs). Matrigel invasion assays revealed that oleandrin and odoroside A significantly inhibited cell invasion in a dose-dependent manner. Invasion was significantly inhibited by 1-50 nM oleandrin and by 1-100 nM odoroside A, which are doses lower than the IC50 values of these drugs for cell viability (Figure 3A,B).

2.3. Oleandrin and Odoroside A Inhibited Octamer-Binding Transcription Factor $3 / 4$ (OCT3/4) and $\beta$-Catenin Expression and Reduced Matrix Metalloproteinase-9 (MMP-9) Secretion in MDA-MB-231 and RT-R-MDA-MB-231 Cells

It has been reported that cancer stem cells (CSCs) exist in tumors and can be a cause of tumor resistance to chemotherapy and irradiation, contributing to cancer metastasis and cancer recurrence [42,43]. Our previous study reported higher expression of CSC markers and epithelial-mesenchymal transition (EMT) markers in RT-R-MDA-MB-231 cells than in MDA-MB-231 cells [44]. Thus, we investigated the effect of oleandrin and odoroside A on CSC marker levels and EMT protein levels. Western blot analysis showed that MDA-MB-231 and RT-R-MDA-MB-231 cells showed high protein levels of OCT3/4, a CSC marker, and $\beta$-catenin, an EMT protein. In addition, as expected, RT-R-MDA-MB-231 cells showed slightly higher expression levels of OCT3/4 and $\beta$-catenin than MDA-MB-231 cells, and the expression of these proteins was significantly inhibited by treatment with oleandrin $(50 \mathrm{nM})$ and odoroside $\mathrm{A}(100 \mathrm{nM})$ for $24 \mathrm{~h}$ (Figure 4A,B). In addition, treatment with oleandrin (50 nM) and odoroside A (100 nM) for $24 \mathrm{~h}$ also effectively reduced MMP-9 activity in both MDA-MB-231 and RT-R-MDA-MB-231 cells (Figure 4C). 


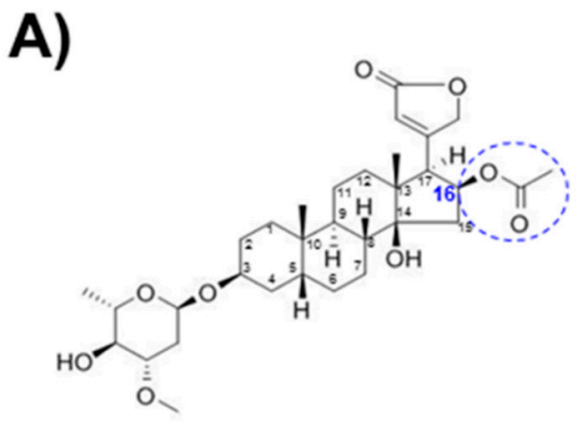

Oleandrin (MW 576.73)

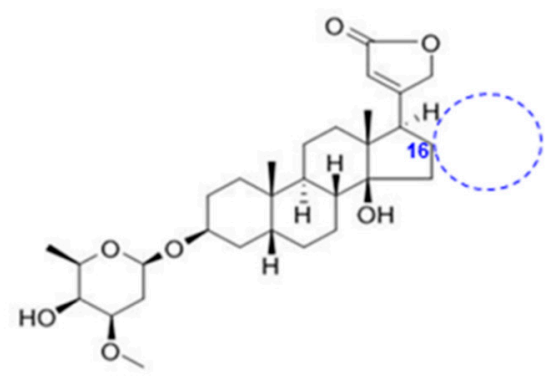

Odoroside A (MW 518.69)

\section{B)}
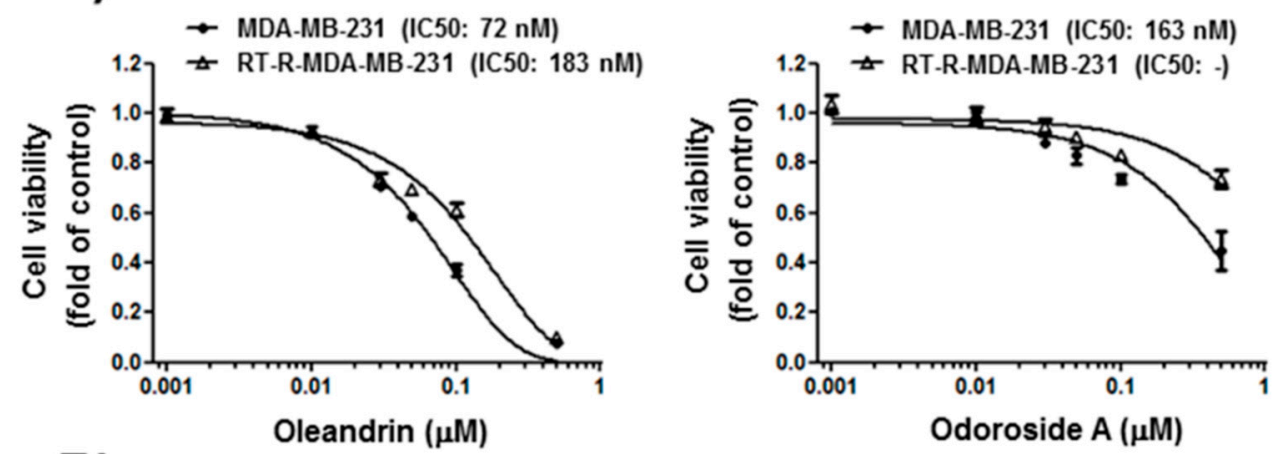

C)
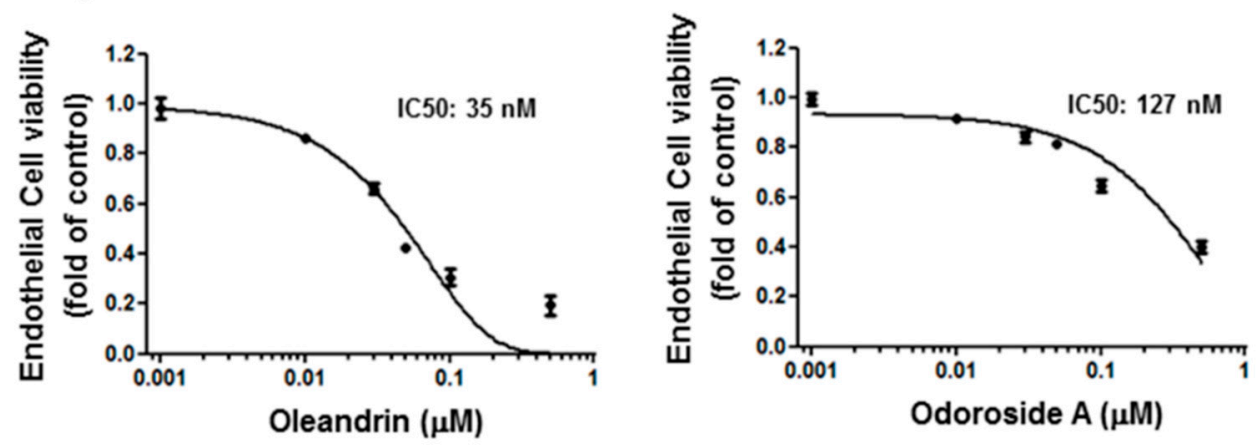

Figure 1. Chemical structure of oleandrin and odoroside $A(A)$ and their effects on cell viability in MDA-MB-231 or RT-R-MDA-MB-231 cells (B) and ECs (C). (B,C) Cells were starved overnight and then treated with oleandrin and odoroside $A$ at the indicated concentrations $(1,10,30,50,100$, and $500 \mathrm{nM})$. After $24 \mathrm{~h}$, cell viability was determined by 3-(4,5-dimethylthiazol-2-yl)-2,5-diphenyltetrazolium bromide (MTT) assay. The values are expressed as the means \pm SEM from three independent determinations. Blue circle in panel A shows the difference in structure between oleandrin and odoroside A. 


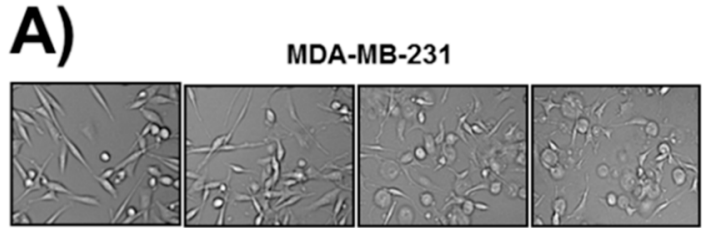

RT-R-MDA-MB-231
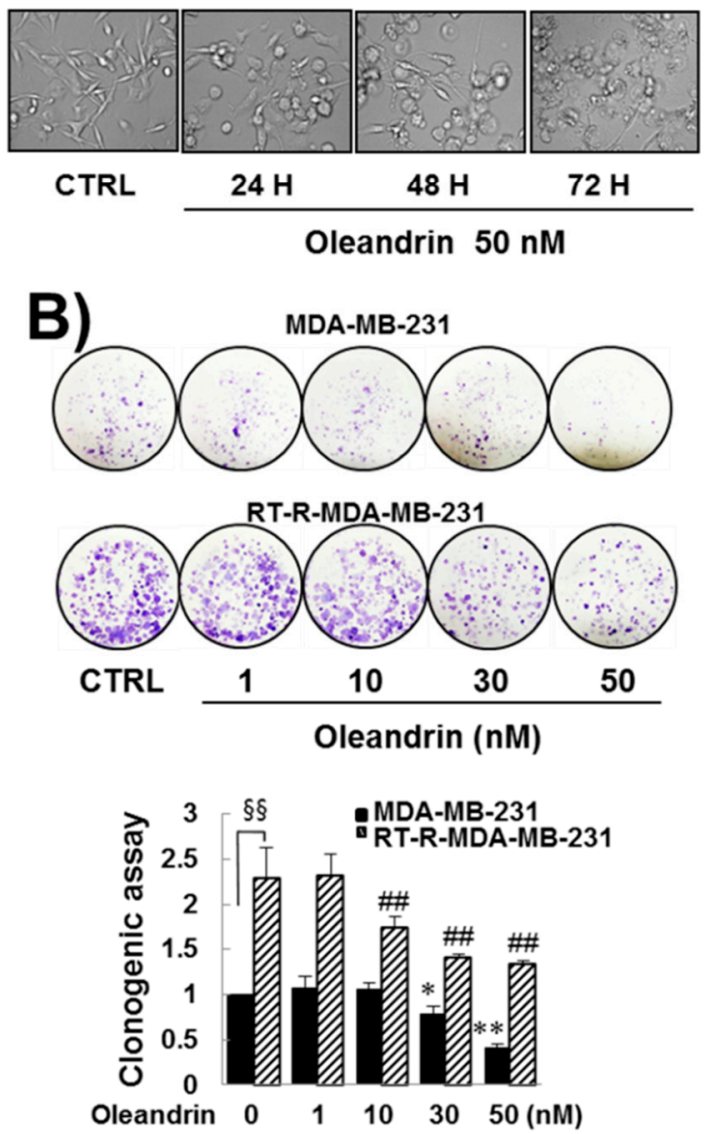

MDA-MB-231

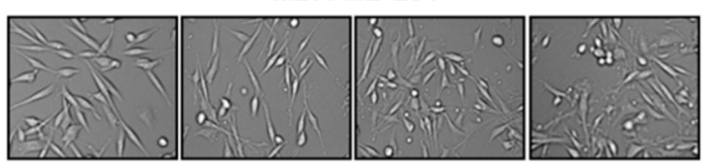

RT-R-MDA-MB-231

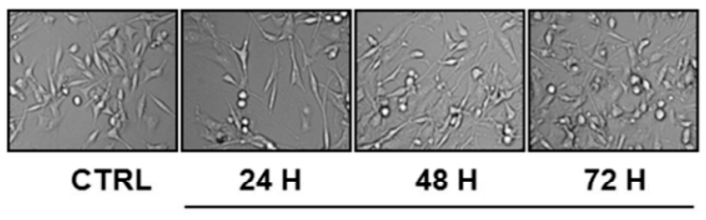

Odoroside A 100 nM

MDA-MB-231

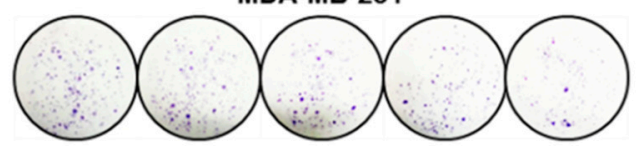

RT-R-MDA-MB-231
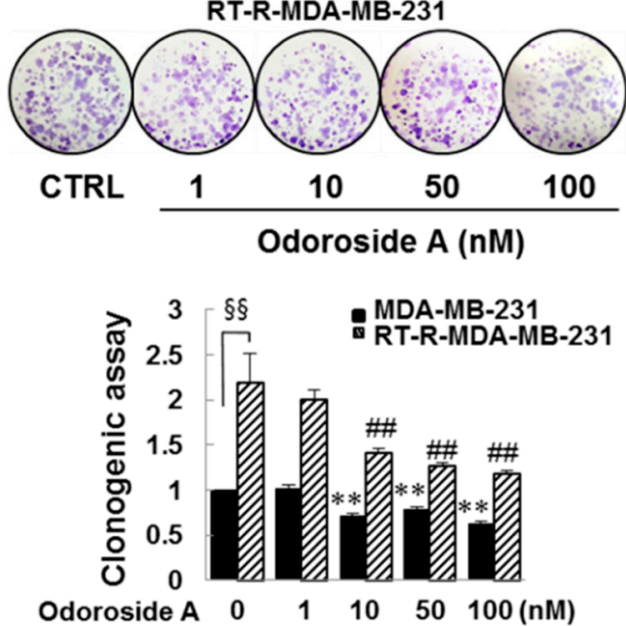

Figure 2. Effects of oleandrin and odoroside A on cell morphology (A) and colony formation (B) in MDA-MB-231 and RT-R-MDA-MB-231 cells. (A) Cells were treated with oleandrin (50 nM) and odoroside A (100 nM) for 24-72 h. Then, the morphologic changes of the cells were observed under a microscope $(200 \times)$. (B) MDA-MB-231 and RT-MDA-MB-231 cells seeded in six-well plates (1000 cells/well) were treated with oleandrin and odoroside A at the indicated doses. After $24 \mathrm{~h}$, the culture medium was discarded and replaced with fresh medium every 2-3 days. After 1-2 weeks, the cells were fixed, stained using crystal violet and counted. The values are expressed as the means \pm SEM from three independent determinations. ${ }^{*} p<0.05,{ }^{* *} p<0.01$ compared with the control group of MDA-MB-231 cells; ${ }^{\#} p<0.01$ compared with control of RT-R-MDA-MB-231 cells. $\S \S p<0.01$ between MDA-MB-231 and RT-R-MDA-MB-231 cells. 
A)
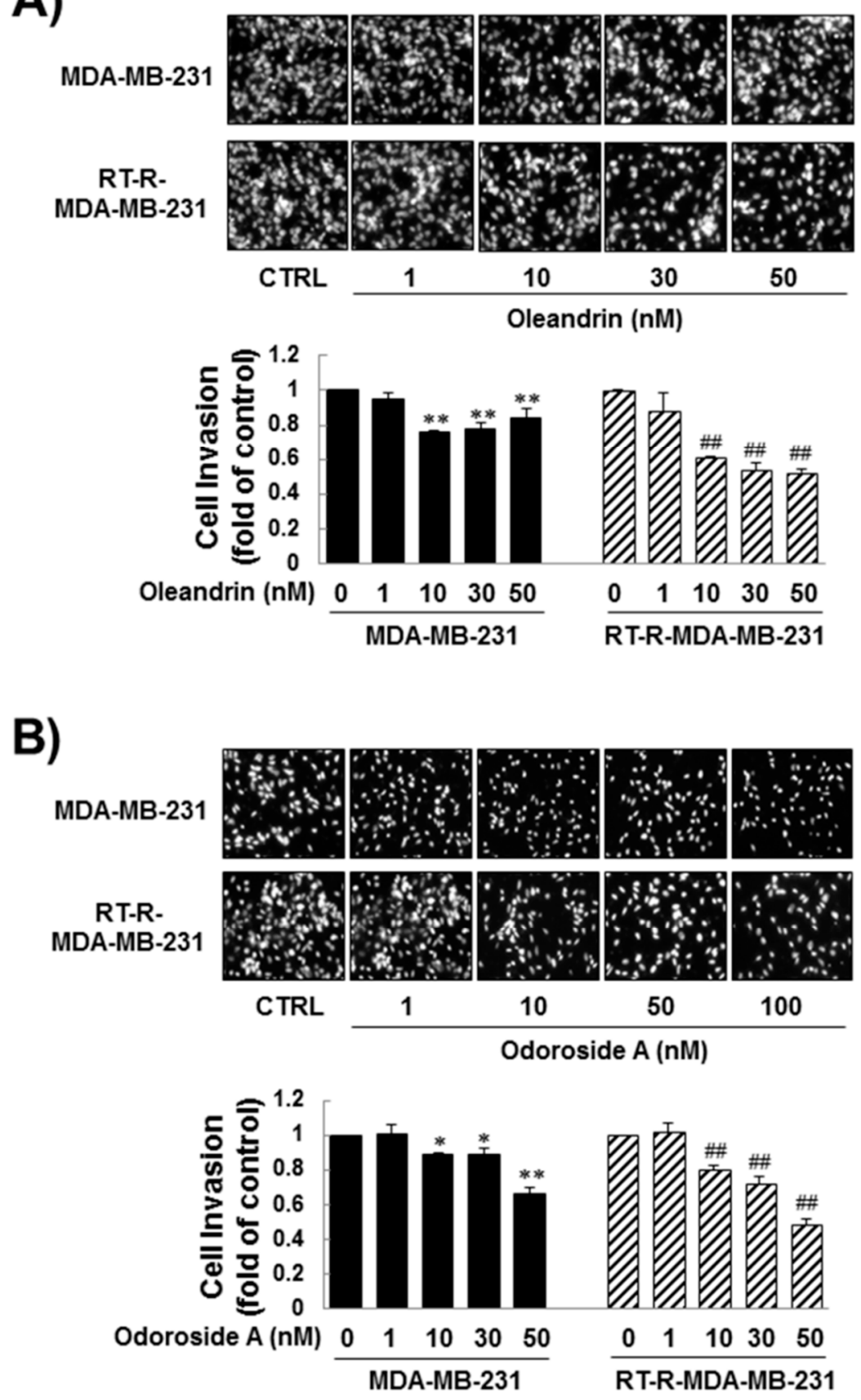

Figure 3. Inhibitory effect of oleandrin and odoroside A on the invasion of MDA-MB-231 and RT-MDA-MB-231 cells. MDA-MB-231 and RT-MDA-MB-231 cells were treated with oleandrin (A) and odoroside A (B) at the indicated concentrations for $24 \mathrm{~h}$, and then the cells were collected, added to ECs-Matrigel-coated insert wells and incubated overnight (for $16 \mathrm{~h}$ ) at $37^{\circ} \mathrm{C}$. The cells that had invaded across the membrane were stained with 4',6-diamidino-2-phenylindole (DAPI) and counted under a fluorescence microscope $(\times 200)$. The values are expressed as the means \pm SEM from three independent determinations. ${ }^{*} p<0.05,{ }^{* *} p<0.01$ compared with the control group of MDA-MB-231 cells; ${ }^{\# \#} p<0.01$ compared with the control group of RT-R-MDA-MB-231 cells. 
A)
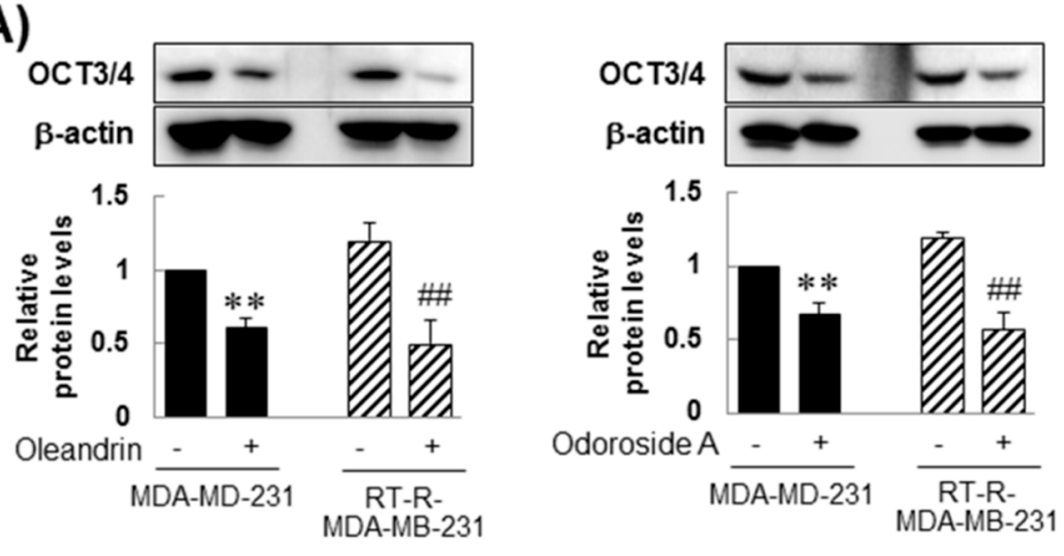

B)
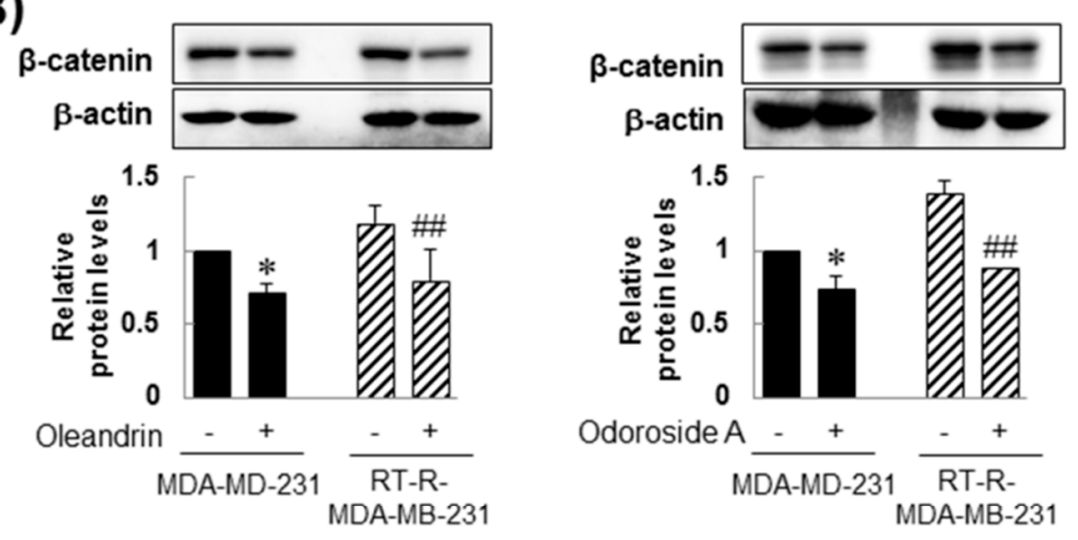

C)
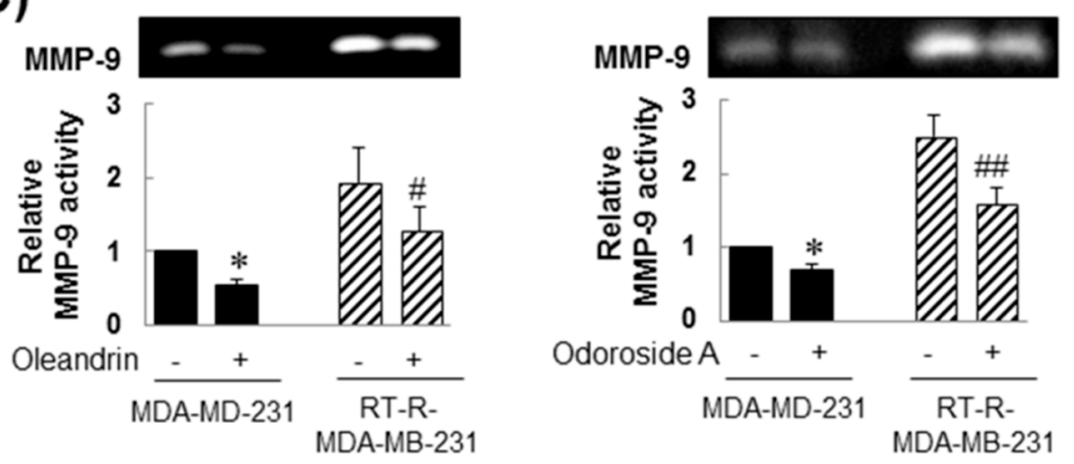

Figure 4. Inhibitory effect of oleandrin and odoroside A on OCT3/4 (A) and $\beta$-catenin expression (B) and MMP-9 secretion (C). Cells were treated with oleandrin $(50 \mathrm{nM})$ and odoroside $\mathrm{A}(100 \mathrm{nM})$ for $24 \mathrm{~h}$. After treatment, OCT3/4, $\beta$-catenin and $\beta$-actin protein levels were determined from the cell lysates by western blot analysis (A,B), and the gelatinolytic activity of MMP-9 was determined from the media by gelatin zymography as described in the Methods $(\mathbf{C})$. The values are expressed as the means \pm SEM from three independent determinations. ${ }^{*} p<0.05,{ }^{* *} p<0.01$ compared with the control group of MDA-MB-231 cells; ${ }^{\# \#} p<0.01$ compared with the control group of RT-R-MDA-MB-231 cells.

2.4. Oleandrin and Odoroside A Down-Regulated STAT-3 Phosphorylation Which Was Induced in $M D A-M B-231$ and $R T-R-M D A-M B-231$

As mentioned in the Introduction, several studies have demonstrated that constitutive activation of STAT-3 occurs in a wide variety of tumors, including breast cancer, and participates in multiple cellular processes as well as in tumorigenesis. Thus, downregulation of STAT-3 has been suggested to overcome chemoresistance and radioresistance. Therefore, in this study, we investigated whether 
the anticancer effects of oleandrin and odoroside A in MDA-MB-231 and RT-R-MDA-MB-231 cells were mediated by modulation of the STAT-3 signaling pathway. Induced levels of phospho-STAT-3 in MDA-MB-231 and RT-R-MDA-MB-231 cells, but not those in ECs, (Figure 5A) were significantly reduced by treatment with oleandrin $(50 \mathrm{nM})$ and odoroside $\mathrm{A}(100 \mathrm{nM})$ for $24 \mathrm{~h}$, as shown in Figure 5B. The inhibitory effects of oleandrin $(50 \mathrm{nM})$ and odoroside A $(100 \mathrm{nM})$ on phospho-STAT-3 were the same as those of AG490 (a specific STAT-3 inhibitor). Moreover, AG490 significantly reduced the levels of OCT3/4 and $\beta$-catenin and the activity of MMP 9 in MDA-MB-231 and RT-R-MDA-MB-231 cells, effects that were similar to the inhibitory effects of oleandrin and odoroside A. Lastly, Figure 6 showed that STAT-3 inhibition by AG490 exhibited a similar effect of oleandrin (50 nM) and odoroside A $(100 \mathrm{nM})$ on breast cancer cell invasion, indicating that the inhibition of STAT-3 phosphorylation by oleandrin and odoroside A mediates inhibition of breast cancer cell invasion.

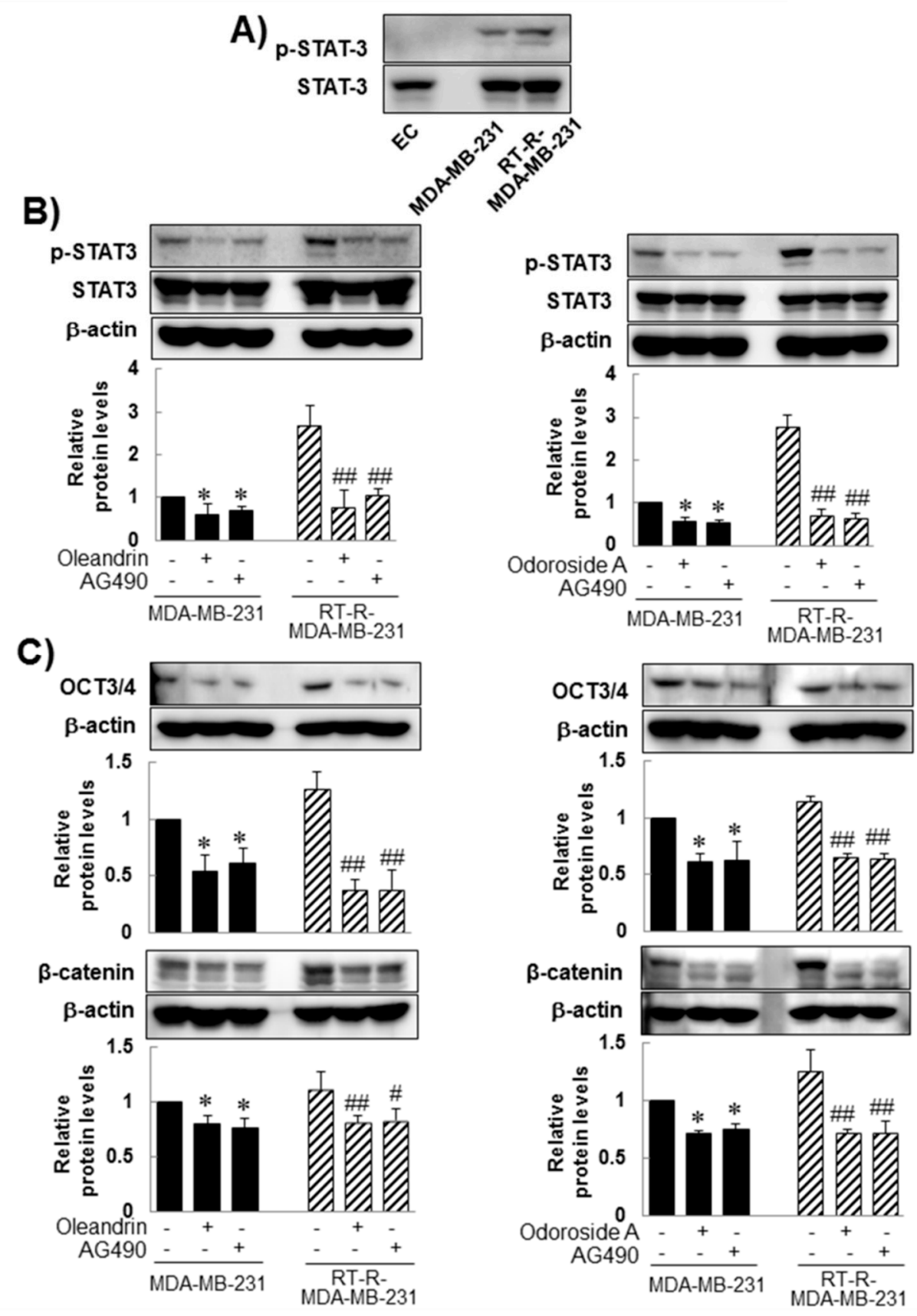

Figure 5. Cont. 

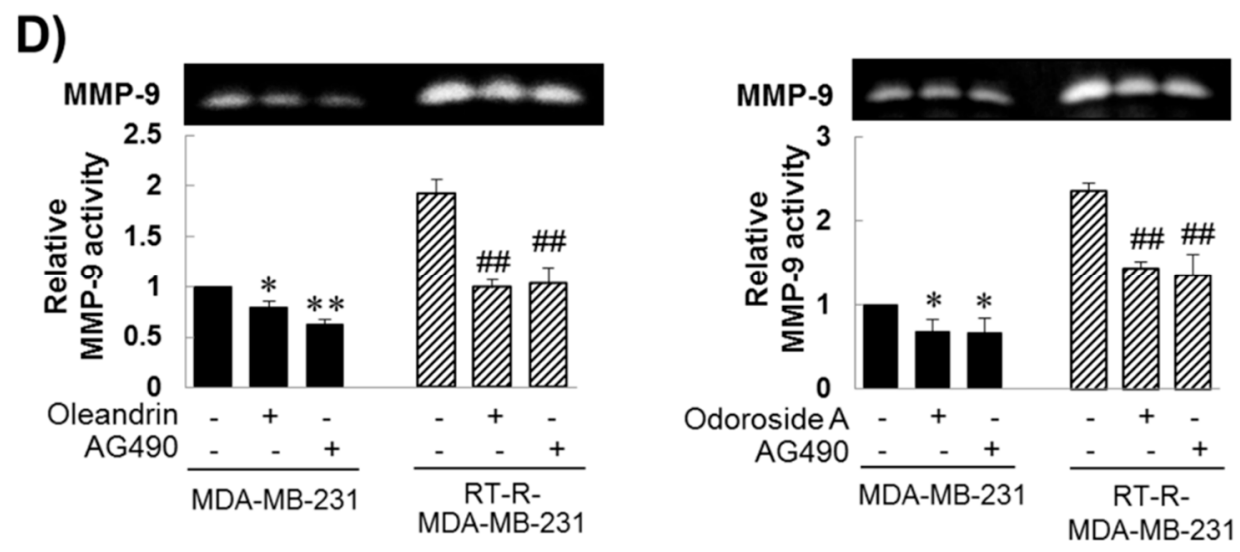

Figure 5. Inhibitory effects of oleandrin and odoroside A on Oct $3 / 4, \beta$-catenin, and MMP-9 through the downregulation of STAT-3 phosphorylation. (A) Phospho-STAT-3 and total STAT-3 protein levels were detected in the cell lysates of ECs, MDA-MB-231 cells and RT-MDA-MB-231 cells by Western blot analysis. (B-E) MDA-MB-231 and RT-R-MDA-MB-231 cells were treated with oleandrin (50 nM), odoroside A (100 nM) and AG490 (10 $\mathrm{MM}$; a phospho-STAT-3 inhibitor) (B-D) for $24 \mathrm{~h}$. After treatment, phospho-STAT-3 (B), OCT3/4 and $\beta$-catenin (C) were determined by Western blot analysis, and MMP-9 activity was determined (D). The values are expressed as the means \pm SEM from three independent determinations. ${ }^{*} p<0.05,{ }^{* *} p<0.01$ compared with the MDA-MB-231 control group; $p<0.05$, \#\# $p<0.01$ compared with the RT-R-MDA control group.

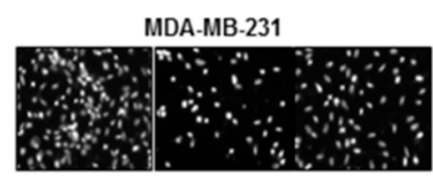

RT-R-MDA-MB-231
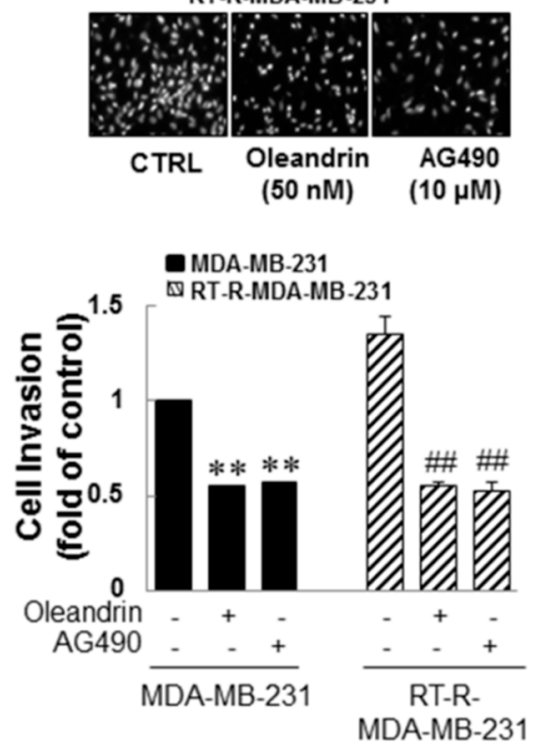

MDA-MB-231

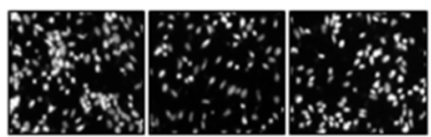

RT-R-MDA-MB-231

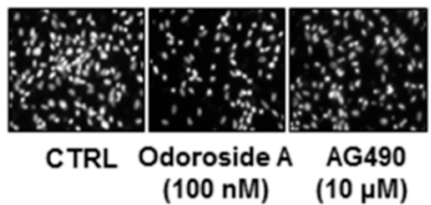

DDA-MB-231

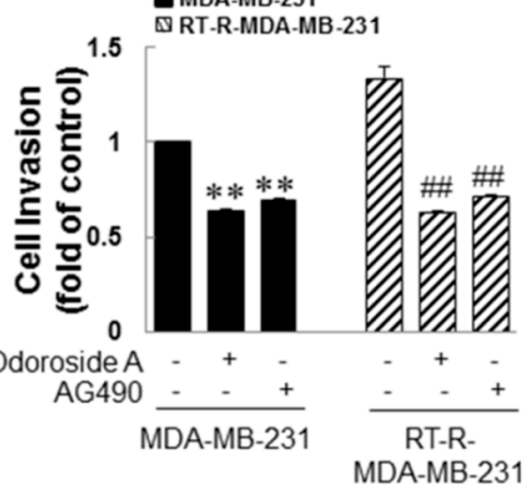

Figure 6. Anticancer effects of oleandrin and odoroside A in MDA-MB-231 and RT-MDA-MB-231 cells through the downregulation of phospho-STAT-3. MDA-MB-231 and RT-MDA-MB-231 cells were treated as described in Figure 5, and then the cells were collected and added to ECs-Matrigel-coated insert wells. The cells were incubated overnight (for $16 \mathrm{~h}$ ) at $37^{\circ} \mathrm{C}$, and then the cells that had invaded across the membrane were stained with DAPI and counted as described in Figure $3(\times 200$ field image). The values are expressed as the means \pm SEM from three independent determinations. ${ }^{* *} p<0.01$ compared with the MDA-MB-231 control group; ${ }^{\# \#} p<0.01$ compared with the RT-R-MDA-MB-231 control group. 


\section{Discussion}

Various natural product-derived drugs play an important role in the oncology field, such as the vinca alkaloids vinblastine and vincristine isolated from Catharanthus roseus L. (Apocynaceae) and paclitaxel obtained from Taxus brevifolia Nutt. (Taxaceae). Among natural products, cardiac glycosides, which are traditionally used in the treatment of congestive heart failure and some arrhythmias because they inhibit NKP, have been attracting researchers' attention for their cytotoxic, antitumor, and anticancer potential $[37,40,45]$. However, although promising data have shown them to be potential anticancer drugs, cardiac glycosides have a narrow therapeutic index due to their cardiovascular toxicity, which has become a barrier for their therapeutic use [36,37]. Some in vitro studies have shown that cardiac glycosides at nanomolar concentrations are nontoxic to normal cells but exhibit anticancer effects in cancer cells $[11,26,38-40]$. Thus, in this study, we aimed to screen cardiac glycosides that were ideally nontoxic or that has an acceptable toxicity to normal cells compared to their beneficial anticancer effect and then to investigate the anticancer effects of the candidates and their underlying mechanisms at safe dose ranges in highly metastatic MDA-MB-231 breast cancer cells and MDA-MB-231-derived radioresistant RT-R-MDA-MB-231 cells.

From preliminary experiments, we found that extract from Nerium oleander, more than any other natural products tested, was effective in inhibiting breast cancer cell invasion. Then, we proceeded to perform further experiments with oleandrin and odoroside $\mathrm{A}$, which are known as active components of Nerium oleander. The results showed that oleandrin and odoroside A significantly decreased the colony formation of both MDA-MB-231 and RT-R-MDA-MB-231 cells at nanomolar ranges (Figure 2C). Moreover, oleandrin and odoroside A significantly inhibited the invasion of both MDA-MB-231 and RT-R-MDA-MB-231 cells through EC-Matrigel-coated transwell membranes (Figure 3) by downregulating the EMT-related protein $\beta$-catenin and the secretion of MMP-9 at 50 and $100 \mathrm{nM}$, respectively (Figure 4B,C). In addition, at the same doses, oleandrin and odoroside $\mathrm{A}$ effectively reduced the levels of the cancer stem cell marker OCT3/4 (Figure 4A). Finally, we found elevated levels of phospho-STAT-3 in MDA-MB-231 and RT-R-MDA-MB-231 cells that were higher in RT-R-MDA-MB-231 cells than in MDA-MB-231 cells (Figure 5A), and these levels were significantly decreased by oleandrin $(50 \mathrm{nM})$ and odoroside A (100 nM) (Figure 5B). Inhibition of phospho-STAT-3 significantly reduced the expression of OCT3/4 and the activity of MMP-9, ultimately resulting in reduced invasion (Figure 5C,D and Figure 6).

Cardenolides are steroidal compounds characterized by the presence of a five-membered unsaturated lactone ring at $\mathrm{C} 17$ that exhibits cardiotonic activity. Cardenolides, together with the bufadienolides, which contain an $\alpha$-pyrone ring, compose the group of so-called cardiac glycosides. Arai et al. [46] compared the anticancer activity of various compounds isolated from Nerium oleander and reported that the sugar moiety at $\mathrm{C} 3$ is important for anticancer activity. In addition, when a double bond at $\mathrm{C} 16$ and $\mathrm{C} 17$ was introduced, the activity decreased, and the $\mathrm{OH}$ group at $\mathrm{C} 8$ also reduced the activity. The difference in structure between oleandrin and odoroside A involves the presence or absence of an acetoxy group at C16, which is not important in conferring significant anticancer activity. According to our results, odoroside A, which has no acetoxy group at C16, shows reduced toxicity to normal ECs as well as to breast cancer cells, such as MDA-MB-231 and RT-R-MDA-MB-231 cells, at nanomolar ranges compared to oleandrin.

During past decades, it has been reported that oleandrin may be a potential antitumor agent, as it can effectively inhibit the proliferation of various cancer cells and induce apoptosis [21,22]. Additionally, oleandrin can enhance the effectiveness of radiotherapy [23]. The suggested mechanisms of oleandrin-mediated inhibition of tumor cell proliferation are as follows: alteration of membrane fluidity [47,48]; reduction of the activation of the nuclear transcription factors nuclear factor kappa B (NF- $\mathrm{KB}$ ), c-Jun N-terminal kinase (JNK) and activator protein-1 (AP-1) [21,49]; elevation of intracellular calcium $[22,36]$ and reactive oxygen species (ROS) production, oxidative injury and mitochondrial injury [22,25,26]; inhibition of fibroblast growth factor-2 (FGF-2) [48]; and weakening of the regulation of IL-8 receptors [50]. Cardenolides, as effective inhibitors of NKP, may regulate other 
signaling pathways. They can modulate the mitogen-activated protein kinase (MAPK)/extracellular signal-regulated kinase (ERK) pathway for antiproliferation by inhibiting NKP [51]. In addition, they also seem to induce autophagy in cancer cells by inhibiting hypoxia-inducible factor 1alpha $(\mathrm{HIF} 1 \alpha)$, mammalian target of rapamycin (mTOR), and ERK1/2 [52-54]. However, the anticancer effects and the related mechanisms are not well understood, even though they may include one or more of those mentioned above for oleandrin.

This study provides important insights into the mechanisms of oleandrin and odoroside A; cardiac glycosides are anticancer agents that target the STAT-3 pathway. Aberrant activation of STATs, especially STAT-3, contributes to tumor progression at several levels. STATs regulate the transcription of target genes controlling tumor cell proliferation and differentiation, as well as genes encoding proteins with major roles in conditioning the tumor microenvironment, for instance, those involved in angiogenesis and the recruitment of immune cells $[27,30]$. In breast cancer, activation of STAT-3 and STAT- 5 is frequently observed in cancer cells, with STAT- 3 often activated in invasive and metastatic tumors [31,32]. Seven STAT proteins have been identified, and of these, STATs 2, 4, and 6 are activated specifically by a small subset of cytokines (IFN $\alpha$, IL-6, 12, and 13, respectively). In contrast, STATs $1,3,5 \mathrm{a}$, and $5 \mathrm{~b}$ can be activated not only by a large array of cytokines but also by growth factors (EGF, PDGF, insulin, IGF-1, and others) and some G-protein coupled receptor agonists [55-57]. Recent studies have focused on the potential role of STATs $(1,3,5 a$, and 5b) in oncogenic pathways [58]. Many STAT-3-regulated genes are involved in prosurvival signaling and the self-renewal of CSCs $[59,60]$. Increased STAT-3 activity has also been linked to the development of chemoresistance in triple-negative breast cancer cells (TNBCs) [61] and has been associated with metastasis promotion in TNBC [62].

Src homology region 2 domain-containing phosphatase 1 (SHP-1), a nonreceptor protein tyrosine phosphatase, is one of the negative regulators of phospho-STAT-3 [63]. In our preliminary data, oleandrin and odoroside A induced SHP-1 expression, which might result in the inhibition of STAT-3 phosphorylation (Supplemental Figure S1). Lee et al. [62] also reported that the herbal compound penta-O-galloyl- $\beta$-D-glycose (PGG) inhibited the JAK-1/STAT-3 axis through the induction of SHP-1 and ultimately suppressed TNBC growth and metastasis.

As mentioned in the Introduction, the $\alpha 1$ and $\alpha 3$ subunits of NKP are frequently overexpressed in colorectal cancer, glioblastomas and breast cancer [13-15], and thus far, it has been the dominant view that the aberrant overexpression and activity of the NKA $\alpha 1$ subunit is related to the progression of various cancers, including breast cancer [17]. The expression levels of NKA $\alpha 1$ in nine different breast cancer cell lines have been examined, and the relative NKA $\alpha 1$ expression in MDA-MB-231 and SKBR-3 cells, which are known as highly metastatic breast cancer cells, was the highest among all nine tested breast cancer cells [64], even though Salyer et al. [65] showed that the expression of $\alpha 1$, $\alpha 3$, and $\beta 3$ was higher in MDA-MB-231 cells than in other breast cancer cells tested (T47D, MCF-7, and MDA-MB-453 cells). Further study to clarify the differential roles of $\alpha 1$ and $\alpha 3$ in breast cancer metastasis is needed, but targeting NKP-STAT-3 signaling may offer a novel therapeutic strategy to treat breast cancer.

\section{Materials and Methods}

\subsection{Materials}

Oleandrin and odoroside A were purchased from Sigma-Aldrich (St. Louis, MO, USA) (Figure 1A). Antibodies against OCT3/4, $\beta$-catenin and SHP-1 were purchased from Santa Cruz Biotechnology (Dallas, TX, USA), and antibodies against phospho-STAT-3 and STAT-3 were obtained from Cell Signaling Technology (Beverly, MA, USA). The BD Matrigel ${ }^{\mathrm{TM}}$ basement membrane matrix was supplied by BD Biosciences (San Diego, CA, USA). The enhanced chemiluminescence (ECL) Western blotting detection reagent was obtained from Bio-Rad (Hercules, CA, USA). All other reagents, including DAPI and an anti- $\beta$-actin antibody, were obtained from Sigma-Aldrich. 


\subsection{Cell Culture}

The human breast cancer cell line MDA-MB-231 was obtained from the Korea Cell Line Bank (Seoul, Korea), and the EA.hy926 human umbilical vascular endothelial cell line was originally purchased from the American Type Culture Collection (Manassas, VA, USA). RT-R-MDA-MB-231 cells were generated as described in a previous study [42]. Briefly, cells were irradiated with 2 Gy using a 6-MV photon beam produced by a linear accelerator (Clinac 21EX, Varian Medical Systems, Inc., Palo Alto, CA, USA) until a final dose of 50 Gy was achieved, which is a commonly used clinical regimen for radiotherapy in patients with breast cancer. The human breast cancer cell lines and EA.hy926 cells were cultured in Roswell Park Memorial Institute medium 1640 (RPMI 1640) and Dulbecco's modification of Eagle medium (DMEM) (HyClone Laboratories, Logan, UT, USA), respectively, both of which were supplemented with $10 \%$ fetal bovine serum (FBS) (HyClone Laboratories), $100 \mathrm{IU} / \mathrm{mL}$ penicillin and $10 \mu \mathrm{g} / \mathrm{mL}$ streptomycin (HyClone Laboratories), and incubated at $37{ }^{\circ} \mathrm{C}$ in a humidified atmosphere containing $5 \% \mathrm{CO}_{2}$ and $95 \%$ air.

\subsection{Cell Viability Assay}

Cells were seeded at a density of $1 \times 10^{4}$ cells/well in 24 -well plates. The cells were treated with oleandrin or odoroside $\mathrm{A}$ at concentrations of $1,10,30,50,100$, and $500 \mathrm{nM}$ at $37^{\circ} \mathrm{C}$ for $24 \mathrm{~h}$ or were treated with $50 \mathrm{nM}$ oleandrin or $100 \mathrm{nM}$ odoroside A for 24 or $48 \mathrm{~h}$. After the removal of media, the cells were washed with PBS and incubated for an additional $3 \mathrm{~h}$ in medium containing $0.1 \mathrm{mg} / \mathrm{mL}$ MTT. The supernatants were aspirated, and the formazan crystals were dissolved with $200 \mu \mathrm{L}$ of $4 \mathrm{~N}$ $\mathrm{HCl}$-isopropanol in each well. The optical density of the colored product was measured at $570 \mathrm{~nm}$, as suggested by the manufacturer, using an Infinite 200 microplate reader (TECAN Austria GmbH, Grödig, Austria).

\subsection{Colony Formation Assay}

MDA-MB-213 cells or RT-R-MDA-MB-231 cells were seeded in six-well plates $\left(1 \times 10^{3}\right.$ cells $/$ well). Then, the cells were treated with oleandrin or odoroside A at the indicated doses at $37^{\circ} \mathrm{C}$ for $24 \mathrm{~h}$. After treatment, the culture medium was discarded and replaced every 2-3 days. After 1-2 weeks, the medium was discarded, and each well was washed with PBS. The colonies were fixed in $100 \%$ methanol for $10 \mathrm{~min}$ at room temperature and stained with $0.1 \%$ Giemsa staining solution for $30 \mathrm{~min}$ at room temperature, and then the visible colonies were counted.

\subsection{Matrigel Invasion Assay}

For the invasion assays, the upper chambers of the inserts were coated with $100 \mu \mathrm{L}$ of Matrigel ( $1 \mathrm{mg} / \mathrm{mL}$, BD Biosciences), and ECs $\left(2 \times 10^{5}\right.$ cells) were added to the Matrigel-coated inserts. MDA-MB-231 cells and RT-R-MDA-MB-231 cells $\left(2 \times 10^{5}\right.$ cells/insert $)$ were treated with oleandrin or odoroside $\mathrm{A}$ at the indicated doses for $24 \mathrm{~h}$ and then added to the upper chambers in serum-free media, and $500 \mu \mathrm{L}$ of RPMI-1640 with $10 \%$ FBS (HyClone Laboratories) was added to the lower chambers. The invasion chambers were incubated overnight $(16 \mathrm{~h})$ in a $37^{\circ} \mathrm{C}$ cell culture incubator. The noninvasive cells that remained on the upper surface of the insert membranes were removed by scrubbing. The cells on the lower insert membranes were stained with DAPI, and the cells were counted under a fluorescence microscope ( $200 \times$ field image, Olympus, Tokyo, Japan).

\subsection{Western Blot Analysis}

Cells were harvested and lysed in RIPA buffer containing $50 \mathrm{mM}$ Tris- $\mathrm{HCl}, \mathrm{pH}$ 7.5, $150 \mathrm{mM}$ $\mathrm{NaCl}, 1 \% \mathrm{NP}-40,0.1 \% \mathrm{SDS}, 0.5 \%$ sodium deoxycholate and protease inhibitors. The samples were centrifuged at $16,000 \times \mathrm{g}$ for $20 \mathrm{~min}$ at $4{ }^{\circ} \mathrm{C}$, and the supernatants were collected for determination of the protein concentration using the Bradford method. Aliquots of 30-50 $\mu \mathrm{g}$ of protein were subjected to $8-10 \%$ sodium dodecyl sulfate-polyacrylamide gel electrophoresis (SDS-PAGE) for $2 \mathrm{~h}$ 
at $100 \mathrm{~V}$. The separated proteins in the SDS-polyacrylamide gel were transferred onto Hybond-P+ polyvinylidene difluoride membranes (Amersham, Buckinghamshire, UK). The membranes were blocked with $5 \%$ nonfat milk in Tris-buffered saline containing $0.05 \%$ Tween- 20 for $1 \mathrm{~h}$ at room temperature and then incubated with the following primary antibodies: anti-OCT3/4 (sc-9081, 1:1000, rabbit polyclonal IgG, Santa Cruz Biotechnology, Inc., Dallas, TX, USA), anti- $\beta$-catenin (sc-7199, 1:1000, rabbit polyclonal IgG, Santa Cruz Biotechnology), anti-phospho-STAT-3 (9131S 1:1000, Cell Signaling Technology, Danvers, MA, USA), anti-STAT-3 (4904S 1:1000, Cell Signaling Technology), and anti-SHP-1 (sc-7289 1:1000, Santa Cruz Biotechnology). The bound antibodies were detected with goat anti-rabbit IgG-horseradish peroxidase-conjugated secondary antibodies (sc-2054, 1:5000, Santa Cruz Biotechnology) and an ECL Western blotting detection reagent (Bio-Rad, Hercules, CA, USA).

\subsection{Gelatin Zymography}

MDA-MB-231 cells or RT-R-MDA-MB-231 cells (90\% confluence) were treated with oleandrin or odoroside $\mathrm{A}$ at the indicated doses for $24 \mathrm{~h}$, and then two milliliters of media was collected from cultured MDA-MB-231 cells or RT-R-MDA-MB-231 cells and concentrated 20-fold using protein concentrators (9K MWCO; Thermo Fisher Scientific, Inc., Waltham, MA, USA). Concentrated media containing the same amount of protein $(40 \mu \mathrm{g} / 20 \mu \mathrm{L})$ were mixed with sample buffer $(0.03 \%$ bromophenol blue, $0.4 \mathrm{M}$ Tris- $\mathrm{HCl} \mathrm{pH} 7.4,20 \%$ glycerol, $5 \%$ SDS) and subjected to electrophoresis on $8 \%$ polyacrylamide gels containing $1 \mathrm{mg} / \mathrm{mL}$ gelatin. The gels were washed with renaturing buffer (2.5\% Triton X-100) for $1 \mathrm{~h}$ and subsequently incubated for $24 \mathrm{~h}$ at $37{ }^{\circ} \mathrm{C}$ in developing buffer (50 mM Tris, $20 \mathrm{mM} \mathrm{NaCl}, 5 \mathrm{mM} \mathrm{CaCl}_{2}$, and $0.02 \%$ Brij35, $\mathrm{pH} 7.5$ ). The gels were stained with 0.05\% Coomassie Brilliant Blue R-250 and destained with 50\% methanol and $10 \%$ acetic acid. Within the blue background, clear zones indicated MMP proteolytic activity.

\subsection{Statistically Analyses}

All results are representative of three independent experiments performed in triplicate. The statistical analysis was performed using SigmaPlot software (version 10.0; Systat Software, Inc., San Jose, CA, USA). The data were analyzed with two-tailed Student's $t$-tests to compare two groups or with one-way analysis of variance with Scheffe's post hoc test to compare mean values across multiple treatment groups. The data are presented as the means \pm standard error.

\section{Conclusions}

Taken together, these results suggest that oleandrin and odoroside A have anticancer effects by inhibiting invasion/metastasis in both MDA-MB-231 and RT-R-MDA-MB-231 cells. In particular, odoroside A has less cytotoxicity to ECs than oleandrin but has similar anticancer effects. The anticancer effects of oleandrin and odoroside A might be due to the suppression of phospho-STAT-3-mediated pathways that are involved in the regulation of invasion-related molecules, such as cancer stem cell markers and EMT-related proteins.

Supplementary Materials: Supplementary materials can be found at http:/ /www.mdpi.com/1422-0067/19/11/ 3350/s1.

Author Contributions: Y.S.K. performed the experiments and statistical analyses, and contributed to preparing the manuscript; T.R. and H.J. performed the experiments and revised the manuscript; S.W.P performed statistical analyses and revised the manuscript; and H.J.K. designed the study, conceived of the hypothesis, directed the project, and wrote the manuscript.

Acknowledgments: This work was supported by the Basic Science Research Program through the National Research Foundation of Korea (NRF) funded by the Ministry of Education, Science and Technology (2015R1A1A3A04001029) (2018R1A2B6001786).

Conflicts of Interest: The authors declare no conflict of interests. 


\section{Abbreviations}

\begin{tabular}{|c|c|}
\hline AP-1 & Activator protein-1 \\
\hline CSC & Cancer stem cell \\
\hline DAPI & 4',6-Diamidino-2-phenyindole, dilactate \\
\hline DMEM & Dulbecco's modification of Eagle medium \\
\hline EC & Endothelial cell \\
\hline ECL & Enhanced chemiluminescence \\
\hline EMT & Epithelial-Mesenchymal Transition \\
\hline ERK & Extracellular signal-regulated kinase \\
\hline FBS & Fetal bovine serum \\
\hline FGF-2 & Fibroblast growth factor-2 \\
\hline HIF1 $\alpha$ & Hypoxia-inducible factor 1alpha \\
\hline IC50 & Inhibitory concentration that decreases cell viability by $50 \%$ \\
\hline JAK & Janus kinase \\
\hline MAPK & Mitogen-activated protein kinase \\
\hline MMP & Matrix metalloproteinase \\
\hline mTOR & Mammalian target of rapamycin \\
\hline MTT & 3-(4,5-Dimethylthiazol-2-yl)-2,5-biphenyl tetrazolium bromide \\
\hline NF- $\kappa \mathrm{B}$ & Nuclear factor kappa B \\
\hline NKP & Sodium/potassium $\left(\mathrm{Na}^{+} / \mathrm{K}^{+}\right)$-ATPase pump \\
\hline OCT & octamer-binding transcription factor \\
\hline ROS & Reactive oxygen species \\
\hline RPMI & Roswell Park Memorial Institute medium \\
\hline RT-R & Radioresistant \\
\hline SDS-PAGE & Sodium dodecyl sulfate-polyacrylamide gel electrophoresis \\
\hline SHP-1 & Src homology region 2 domain-containing phosphatase 1 \\
\hline STAT & Signal transducer and activator of transcription \\
\hline TNBC & Triple negative breast cancer \\
\hline
\end{tabular}

\section{References}

1. Pressley, T.A. Structure and function of the Na, K pump: Ten years of molecular biology. Miner. Electrolyte Metab. 1996, 22, 264-271. [PubMed]

2. Leu, W.J.; Chang, H.S.; Chan, S.H.; Hsu, J.L.; Yu, C.C.; Hsu, L.C.; Chen, I.S.; Guh, J.H. Reevesioside A, a cardenolide glycoside, induces anticancer activity against human hormone-refractory prostate cancers through suppression of c-Myc expression and induction of G1 arrest of the cell cycle. PLoS ONE 2014, 9, e87323. [CrossRef] [PubMed]

3. Chan, S.H.; Leu, W.J.; Hsu, L.C.; Chang, H.S.; Hwang, T.L.; Chen, I.S.; Chen, C.S.; Guh, J.H. Reevesioside F induces potent and efficient anti-proliferative and apoptotic activities through $\mathrm{Na}^{+} / \mathrm{K}^{+}$-ATPase $\alpha 3$ subunit-involved mitochondrial stress and amplification of caspase cascades. Biochem. Pharmacol. 2013, 86, 1564-1575. [CrossRef] [PubMed]

4. Forrest, M.D.; Wall, M.J.; Press, D.A.; Feng, J. The sodium-potassium pump controls the intrinsic firing of the cerebellar Purkinje neuron. PLoS ONE 2012, 7, e51169. [CrossRef] [PubMed]

5. Paul, D.; Soignier, R.D.; Minor, L.; Tau, H.; Songu-Mize, E.; Gould, H.J., 3rd. Regulation and pharmacological blockade of sodium-potassium ATPase: A novel pathway to neuropathy. J. Neurol. Sci. 2014, 340, 139-143. [CrossRef] [PubMed]

6. Espineda, C.; Seligson, D.B.; James Ball, W., Jr.; Rao, J.; Palotie, A.; Horvath, S.; Huang, Y.; Shi, T.; Rajasekaran, A.K. Analysis of the Na, K ATPase $\alpha$ - and $\beta$-subunit expression profiles of bladder cancer using tissue microarrays. Cancer 2003, 97, 1859-1868. [CrossRef] [PubMed]

7. Blok, L.J.; Chang, G.T.; Steenbeek-Slotboom, M.; van Weerden, W.M.; Swarts, H.G.; de Pont, J.J.; van Steenbrugge, G.J.; Brinkmann, A.O. Regulation of expression of $\mathrm{Na}^{+}, \mathrm{K}^{+}$-ATPase in androgen-dependent and androgen-independent prostate cancer. Br. J. Cancer 1999, 81, 28-36. [CrossRef] [PubMed] 
8. Rajasekaran, S.A.; Ball, W.J., Jr.; Bander, N.H.; Liu, H.; Pardee, J.D.; Rajasekaran, A.K. Reduced expression of beta-subunit of $\mathrm{Na}^{+}, \mathrm{K}^{+}$-ATPase in human clear-cell renal cell carcinoma. J. Urol. 1999, 162, 574-580. [CrossRef]

9. Rajasekaran, S.A.; Hu, J.; Gopal, J.; Gallemore, R.; Ryazantsev, S.; Bok, D.; Rajasekaran, A.K. Na ${ }^{+} \mathrm{K}^{+}$-ATPase inhibition alters tight junction structure and permeability in human retinal pigment epithelial cells. Am. J. Physiol. Cell Physiol. 2003, 284, C1497-C1507. [CrossRef] [PubMed]

10. Kometiani, P.; Liu, L.; Askari, A. Digitalis-induced signaling by $\mathrm{Na}^{+}, \mathrm{K}^{+}$-ATPase in human breast cancer cells. Mol. Pharmacol. 2005, 67, 929-936. [CrossRef] [PubMed]

11. Hsu, J.L.; Liu, F.L.; Hsu, L.C.; Chang, H.S.; Leu, W.J.; Yu, C.C.; Chang, W.L.; Chen, I.S.; Kung, F.L.; Guh, J.H. EPI-reevesioside $\mathrm{F}$ inhibits $\mathrm{Na}^{+}, \mathrm{K}^{+}$-ATPase, causing cytosolic acidification, BAK activation and apoptosis in glioblastoma. Oncotarget 2015, 6, 24032-24046. [CrossRef] [PubMed]

12. Blanco, G.; Mercer, R.W. Isozymes of the $\mathrm{Na}^{+}, \mathrm{K}^{+}$-ATPase: Heterogeneity in structure, diversity in function. Am. J. Physiol. 1998, 275, F633-F650. [CrossRef] [PubMed]

13. Lefranc, F.; Mijatovic, T.; Kondo, Y.; Sauvage, S.; Roland, I.; Debeir, O.; Krstic, D.; Vasic, V.; Gailly, P.; Kondo, S.; et al. Targeting the $\alpha-1$ subunit of the sodium pump to combat glioblastoma cells. Neurosurgery 2008, 62, 211-221. [CrossRef] [PubMed]

14. Sakai, H.; Suzuki, T.; Maeda, M.; Takahashi, Y.; Horikawa, N.; Minamura, T.; Tsukada, K.; Takeguchi, N. Up-regulation of $\mathrm{Na}^{+}, \mathrm{K}^{+}$-ATPase $\alpha 3$-isoform and down-regulation of the $\alpha 1$-isoform in human colorectal cancer. FEBS Lett. 2004, 563, 151-154. [CrossRef]

15. Winnicka, K.; Bielawski, K.; Bielawska, A.; Surazynski, A. Antiproliferative activity of derivatives of ouabain, digoxin and proscillaridin in human MCF-7 and MDA-MB-231 breast cancer cells. Biol. Pharm. Bull. 2008, 31, 1131-1140. [CrossRef] [PubMed]

16. Repke, K.; Portius, H.J. Comparison of the effect of steroid lactones on the transport-ATPase and ion transport of erythrocytes. Folia Haematol. Int. Mag. Klin. Morphol. Blutforsch 1965, 83, 108-118. [PubMed]

17. Kelly, R.A.; Smith, T.W. Pharmacological treatment of heart failure. In The Pharmacological Basis of Therapeutics, 9th ed.; Goodman, L.S., Gilman, A., Eds.; McGraw-Hill: New York, NY, USA, 1996; pp. 809-838. ISBN -10 0078642426.

18. Kepp, O.; Menger, L.; Vacchelli, E.; Adjemian, S.; Martins, I.; Ma, Y.; Sukkurwala, A.Q.; Michaud, M.; Galluzzi, L.; Zitvogel, L.; et al. Anticancer activity of cardiac glycosides: At the frontier between cell-autonomous and immunological effects. Oncoimmunology 2012, 1, 1640-1642. [CrossRef] [PubMed]

19. Menger, L.; Vacchelli, E.; Kepp, O.; Eggermont, A.; Tartour, E.; Zitvogel, L.; Kroemer, G.; Galluzzi, L. Trial watch: Cardiac glycosides and cancer therapy. Oncoimmunology 2013, 2, e23082. [CrossRef] [PubMed]

20. Calderón-Montaño, J.M.; Burgos-Morón, E.; Orta, M.L.; Maldonado-Navas, D.; García-Domínguez, I.; López-Lázaro, M. Evaluating the cancer therapeutic potential of cardiac glycosides. BioMed Res. Int. 2014, 2014, 794930. [CrossRef] [PubMed]

21. Manna, S.K.; Sah, N.K.; Newman, R.A.; Cisneros, A.; Aqqarwal, B.B. Oleandrin suppresses activation of nuclear transcription factor- $\mathrm{kB}$, activator protein-1, and c-Jun NH2-terminal kinase. Cancer Res. 2000, 60, 3838-3847. [PubMed]

22. McConkey, D.J.; Lin, Y.; Nutt, L.K.; Ozel, H.Z.; Newman, R.A. Cardiac glycosides stimulate $\mathrm{Ca}^{2+}$ increases and apoptosis in androgen-independent, metastatic human prostate adenocarcinoma cells. Cancer Res. 2000, 60, 3807-3812. [PubMed]

23. Nasu, S.; Milas, L.; Kawabe, S.; Raju, U.; Newman, R.A. Enhancement of radiotherapy by oleandrin is a caspase-3 dependent process. Cancer Lett. 2002, 185, 145-151. [CrossRef]

24. Yang, P.; Menter, D.G.; Cartwright, C.; Chan, D.; Dixon, S.; Suraokar, M.; Mendoza, G.; Llansa, N.; Newman, R.A. Oleandrin-mediated inhibition of human tumor cell proliferation: Importance of $\mathrm{Na}^{+}, \mathrm{K}^{+}$-ATPase $\alpha$ subunits as drug targets. Mol. Cancer Ther. 2009, 8, 2319-2328. [CrossRef] [PubMed]

25. Newman, R.A.; Yang, P.; Hittelman, W.N.; Lu, T.; Ho, D.H.; Ni, D.; Chan, D.; Vijjeswarapu, M.; Cartwright, C.; Dixon, S.; et al. Oleandrin-mediated oxidative stress in human melanoma cells. J. Exp. Ther. Oncol. 2006, 5, 167-181. [PubMed]

26. Newman, R.A.; Kondo, Y.; Yokoyama, T.; Dixon, S.; Cartwright, C.; Chan, D.; Johansen, M.; Yang, P. Autophagic cell death of human pancreatic tumor cells mediated by oleandrin, a lipid-soluble cardiac glycoside. Integr. Cancer Ther. 2007, 6, 354-364. [CrossRef] [PubMed] 
27. Yu, H.; Jove, R. The STATs of cancer-New molecular targets come of age. Nat. Rev. Cancer 2004, 4, 97-105. [CrossRef] [PubMed]

28. Carpenter, R.L.; Lo, H.W. STAT3 target genes relevant to human cancers. Cancers 2014, 6, 897-925. [CrossRef] [PubMed]

29. Li, N.; Grivennikov, S.I.; Karin, M. The unholy trinity: Inflammation, cytokines, and STAT3 shape the cancer microenvironment. Cancer Cell 2011, 19, 429-431. [CrossRef] [PubMed]

30. Yu, H.; Pardoll, D.; Jove, R. STATs in cancer inflammation and immunity: A leading role for STAT3. Nat. Rev. Cancer 2009, 9, 798-809. [CrossRef] [PubMed]

31. Walker, S.R.; Nelson, E.A.; Zou, L.; Chaudhury, M.; Signoretti, S.; Richardson, A.; Frank, D.A. Reciprocal effects of STAT5 and STAT3 in breast cancer. Mol. Cancer Res. 2009, 7, 966-976. [CrossRef] [PubMed]

32. Sansone, P.; Bromberg, J. Targeting the interleukin-6/Jak/stat pathway in human malignancies. J. Clin. Oncol. 2012, 30, 1005-1014. [CrossRef] [PubMed]

33. Marotta, L.L.; Almendro, V.; Marusyk, A.; Shipitsin, M.; Schemme, J.; Walker, S.R.; Bloushtain-Qimron, N.; Kim, J.J.; Choudhury, S.A.; Maruyama, R.; et al. The JAK2/STAT3 signaling pathway is required for growth of $\mathrm{CD}_{4} 4^{+} \mathrm{CD} 24^{-}$stem cell-like breast cancer cells in human tumors. J. Clin. Invest. 2011, 121, 2723-2735. [CrossRef] [PubMed]

34. Tan, Q.; Wang, H.; Hu, Y.; Hu, M.; Li, X.; Aodengqimuge.; Ma, Y.; Wei, C.; Song, L. Src/STAT3-dependent heme oxygenase-1 induction mediates chemoresistance of breast cancer cells to doxorubicin by promoting autophagy. Cancer Sci. 2015, 106, 1023-1032. [CrossRef] [PubMed]

35. Bonner, J.A.; Trummell, H.Q.; Willey, C.D.; Plants, B.A.; Raisch, K.P. Inhibition of STAT-3 results in radiosensitization of human squamous cell carcinoma. Radiother. Oncol. 2009, 92, 339-344. [CrossRef] [PubMed]

36. Schoner, W.; Scheiner-Bobis, G. Endogenous and exogenous cardiac glycosides: Their roles in hypertension, salt metabolism, and cell growth. Am. J. Physiol. Cell Physiol. 2007, 293, C509-C536. [CrossRef] [PubMed]

37. Newman, R.A.; Yang, P.; Pawlus, A.D.; Block, K.I. Cardiac glycosides as novel cancer therapeutic agents. Mol. Interv. 2008, 8, 36-49. [CrossRef] [PubMed]

38. Abramowitz, J.; Dai, C.; Hirschi, K.K.; Dmitrieva, R.I.; Doris, P.A.; Liu, L.; Allen, J.C. Ouabain- and marinobufagenin-induced proliferation of human umbilical vein smooth muscle cells and a rat vascular smooth muscle cell line, A7r5. Circulation 2003, 108, 1049-1054. [CrossRef] [PubMed]

39. Trevisi, L.; Visentin, B.; Cusinato, F.; Pighin, I.; Luciani, S. Antiapoptotic effect of ouabain in human umbilical vein endothelial cells. Biochem. Biophys. Res. Commun. 2004, 321, 716-721. [CrossRef] [PubMed]

40. Cerella, C.; Dicato, M.; Diederich, M. Assembling the puzzle of anti-cancer mechanisms triggered by cardiac glycosides. Mitochondrion 2013, 13, 225-234. [CrossRef] [PubMed]

41. Rashan, L.J.; Franke, K.; Khine, M.M.; Kelter, G.; Fiebig, H.H.; Neumann, J.; Wessjohann, L.A. Characterization of the anticancer properties of monoglycosidic cardenolides isolated from Nerium oleander and Streptocaulon tomentosum. J. Ethnopharmacol. 2011, 134, 781-788. [CrossRef] [PubMed]

42. Clevers, H. The cancer stem cell: Premises, promises and challenges. Nat. Med. 2011, 17, 313-319. [CrossRef] [PubMed]

43. Sato, R.; Semba, T.; Saya, H.; Arima, Y. Concise review: Stem cells and epithelial-mesenchymal transition in cancer: Biological implications and therapeutic targets. Stem Cells 2016, 34, 1997-2007. [CrossRef] [PubMed]

44. Ko, Y.S.; Jin, H.; Joo, Y.; Lee, J.S.; Park, S.W.; Chang, K.C.; Kang, K.M.; Jeong, B.K.; Kim, H.J. Radio-resistant breast cancer cells derived from highly metastatic breast cancer cells exhibit increased resistance to chemotherapy, enhanced invasive properties and premetastatic niche formation due to cancer stem cells. Oncol. Rep. 2018, 40, 3752-3762.

45. Passas, I.; Diamandis, E.P. Novel therapeutic applications of cardiac glycosides. Nat. Rev. Drug Discov. 2008, 7, 926-935. [CrossRef] [PubMed]

46. Arai, M.A.; Akamine, R.; Tsuchiya, A.; Yoneyama, T.; Koyano, T.; Kowithayakorn, T.; Ishibashi, M. The Notch inhibitor cowanin accelerates nicastrin degradation. Sci. Rep. 2018, 8, 5376. [CrossRef] [PubMed]

47. Manna, S.K.; Sreenivasan, Y.; Sarkar, A. Cardiac glycoside inhibits IL-8 induced biological responses by downregulating IL-8 receptors through altering membrane fluidity. J. Cell Physiol. 2006, 207, 195-207. [CrossRef] [PubMed] 
48. Smith, J.A.; Madden, T.; Vijjeswarapu, M.; Newman, R.A. Inhibition of export of fibroblast growth factor-2 (FGF-2) from the prostate cancer cell lines PC3 and DU145 by Anvirzel and its cardiac glycoside component, oleandrin. Biochem. Pharmacol. 2001, 62, 469-472. [CrossRef]

49. Sreenivasan, Y.; Sarkar, A.; Manna, S.K. Oleandrin suppresses activation of nuclear transcription factor- $\mathrm{kB}$ and activator protein-1 and potentiates apoptosis induced by ceramide. Biochem. Pharmacol. 2003, 66, 2223-2239. [CrossRef] [PubMed]

50. Raghavendra, R.B.; Sreenivasan, Y.; Ramesh, G.T.; Manna, S.K. Cardiac glycoside induces cell death via FasL by activating calcineurin and NF-AT, but apoptosis initially proceeds through activation of caspases. Apoptosis 2007, 12, 307-318. [CrossRef] [PubMed]

51. Ye, Q.; Lai, F.; Banerjee, M.; Duan, Q.; Li, Z.; Si, S.; Xie, Z. Expression of mutant $\alpha 1 \mathrm{Na}^{+}, \mathrm{K}^{+}$-ATPase defective in conformational transition attenuates Src-mediated signal transduction. J. Biol. Chem. 2013, 288, 5803-5814. [CrossRef] [PubMed]

52. Mijatovic, T.; Kiss, R. Cardiotonic steroids-mediated $\mathrm{Na}^{+}, \mathrm{K}^{+}$-ATPase targeting could circumvent various chemoresistance pathways. Planta Med. 2013, 79, 189-198. [CrossRef] [PubMed]

53. Wei, D.; Peng, J.J.; Gao, H.; Li, H.; Li, D.; Tan, Y.; Zhang, T. Digoxin downregulates NDRG1 and VEGF through the inhibition of HIF-1 $\alpha$ under hypoxic conditions in human lung adenocarcinoma A549 cells. Int. J. Mol. Sci. 2013, 14, 7273-7285. [CrossRef] [PubMed]

54. Wang, Y.; Zhan, Y.; Xu, R.; Shao, R.; Jiang, J.; Wang, Z. Srcmediates extracellular signalregulated kinase 1/2 activation and autophagic cell death induced by cardiac glycosides in human non-small cell lung cancer cell lines. Mol. Carcinog. 2015, 54, E26-E34. [CrossRef] [PubMed]

55. Brivanlou, A.H.; Darnell, J.E., Jr. Signal transduction and the control of gene expression. Science 2002, 295, 813-818. [CrossRef] [PubMed]

56. Levy, D.E.; Darnell, J.E., Jr. Stats: Transcriptional control and biological impact. Nat. Rev. Mol. Cell Biol. 2002, 3, 651-662. [CrossRef] [PubMed]

57. O'Shea, J.J.; Gadina., M.; Schreiber, R.D. Cytokine signaling in 2002: New surprises in the Jak/Stat pathway. Cell 2002, 109, S121-S131.

58. Calo, V.; Migliavacca, M.; Bazan, V.; Macaluso, M.; Buscemi, M.; Gebbia, N.; Russo, A. STAT proteins: From normal control of cellular events to tumorigenesis. J. Cell Physiol. 2003, 197, 157-168. [CrossRef] [PubMed]

59. Tan, F.H.; Putoczki, T.L.; Stylli, S.S.; Luwor, R.B. The role of STAT3 signaling in mediating tumor resistance to cancer therapy. Curr. Drug Targets 2014, 15, 1341-1353. [CrossRef] [PubMed]

60. Yao, X.; Zhu, F.; Zhao, Z.; Liu, C.; Luo, L.; Yin, Z. Arctigenin enhances chemosensitivity of cancer cells to cisplatin through inhibition of the STAT3 signaling pathway. J. Cell Biochem. 2011, 112, 2837-2849. [CrossRef] [PubMed]

61. Gariboldi, M.B.; Ravizza, R.; Molteni, R.; Osella, D.; Gabano, E.; Monti, E. Inhibition of STAT3 increases doxorubicin sensitivity in a human metastatic breast cancer cell line. Cancer Lett. 2007, 258, 181-188. [CrossRef] [PubMed]

62. Lee, H.J.; Seo, N.J.; Jeong, S.J.; Park, Y.; Jung, D.B.; Koh, W.; Lee, E.O.; Ahn, K.S.; Lu, J.; Kim, S.H. Oral administration of penta-O-galloyl- $\beta$-D-glucose suppresses triple-negative breast cancer xenograft growth and metastasis in strong association with JAK1-STAT3 inhibition. Carcinogenesis 2011, 32, 804-811. [CrossRef] [PubMed]

63. Lopez-Ruiz, P.; Rodriguez-Ubreva, J.; Cariaga, A.E.; Cortes, M.A.; Colas, B. SHP-1 in cell-cycle regulation. Anticancer Agents Med. Chem. 2011, 11, 89-98. [CrossRef] [PubMed]

64. Wang, Q.; Li, S.B.; Zhao, Y.Y.; Dai, D.N.; Du, H.; Lin, Y.Z.; Ye, J.C.; Zhao, J.; Xiao, W.; Mei, Y.; et al. Identification of a sodium pump $\mathrm{Na}^{+}, \mathrm{K}^{+}$-ATPase $\alpha 1$-targeted peptide for PET imaging of breast cancer. J. Control Release 2018, 281, 178-188. [CrossRef] [PubMed]

65. Salyer, S.A.; Olberding, J.R.; Distler, A.A.; Lederer, E.D.; Clark, B.J.; Delamere, N.A.; Khundmiri, S.J. Vacuolar ATPase driven potassium transport in highly metastatic breast cancer cells. Biochim. Biophys. Acta. 2013, 1832, 1734-1743. [CrossRef] [PubMed]

(C) 2018 by the authors. Licensee MDPI, Basel, Switzerland. This article is an open access article distributed under the terms and conditions of the Creative Commons Attribution (CC BY) license (http://creativecommons.org/licenses/by/4.0/). 